\title{
Ukuran Perusahaan, Good Corporate Governance, Eco-Control dan Luas Pengungkapan Corporate Social Responsibilty
}

\author{
Nengah Saraswati Kusumaputri ${ }^{1}$ \\ Fakultas Ekonomi dan Bisnis \\ Universitas Udayana, Indonesia
}

\section{Ni Putu Sri Harta Mimba ${ }^{2}$ \\ Fakultas Ekonomi dan Bisnis \\ Universitas Udayana, Indonesia}

Surel : saraswatikusumaputri@gmail.com

ABSTRAK

Beberapa tahun terakhir tanggungjawab sosial perusahaan atau biasa disebut corporate social responsibility (CSR) menjadi sebuah isu perkembangan utama suatu perusahaan. Dalam menjalankan kegiatannya, perusahaan tidak terlepas dengan lingkungan dan masyarakat. Perusahaan yang memiliki keinginan untuk tetap bertahan serta memiliki keunggulan kompetitif maka perlu menjadikan CSR sebagai salah satu strategi bisnisnya. Mengetahui bagaimana pengaruh ukuran perusahaan, GCG, dan eco-control terhadap luas pengungkapan CSR merupakan tujuan penelitian ini. Populasi yang digunakan dalam penelitian ini adalah sejumlah perusahaan terdaftar di BEI periode 2017-2019 serta termasuk perusahaan sektor penghasil bahan baku. Sampel yang digunakan sebanyak 11 perusahaan melalui metode purposive sampling. Penelitian ini menggunakan teknik analisis regresi linier berganda. Hasil penelitian yang dapat ditarik dari prnrlitian ini ukuran perusahaan, GCG, dan eco-control memiliki pengaruh terhadap luas pengungkapan CSR.

Kata Kunci: Luas Pengungakapan CSR; Ukuran Perusahaan; Good Corporate Governance; Eco-Control.

\section{Company Size, Good Corporate Governance, Eco-Control and Wide Disclosure of Corporate Social Responsibility}

\begin{abstract}
In recent years, corporate social responsibility or commonly known as corporate social responsibility (CSR) has become a major development issue for a company. In carrying out its activities, the company is inseparable from the environment and society. Companies that have the desire to survive and have a competitive advantage need to make CSR as one of their business strategies. Knowing how company size, GCG, and eco-control influence the extent of CSR disclosure is the aim of this study. The population used in this study is a number of companies listed on the IDX for the 2017-2019 period and including companies in the raw material producing sector. The sample used was 11 companies through purposive sampling method. This study uses multiple linear regression analysis techniques. The results of the study that can be drawn from this study, company size, GCG, and eco-control have an influence on the extent of CSR disclosure.
\end{abstract}

Keywords: $\quad$ Extent Of Corporate Social Responsibility Disclosure; Company Size; Good Corporate Governance; EcoControl.

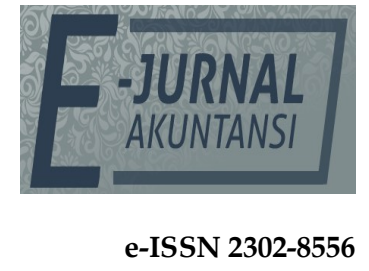

Vol. 31 No. 7

Denpasar, Juli 2021

Hal. 1798-1812

10.24843/EJA.2021.v31.i07.p15

PENGUTIPAN:

Kusumaputri, N.S., \&

Mimba, N.P.S. (2021).

Ukuran Perusahaan, Good

Corporate Governance, Eco-

Control dan Luas

Pengungkapan Corporate

Social Responsibilty. E-Jurnal

Akuntansi, 31(7), 1798-1812

\section{RIWAYAT ARTIKEL:}

Artikel Masuk:

21 November 2020

Artikel Diterima:

15 Februari 2021

Artikel dapat diakses: https://ojs.unud.ac.id/index.php/Akuntansi/index 


\section{PENDAHULUAN}

Di era sekarang tuntutan sebuah perusahaan semakin besar, tidak hanya dituntut untuk mengejar profit, perusahaan juga harus memerhatikan pemenuhan kesejahteraan masyarakat serta aktif berkontribusi dalam menjaga kelestarian lingkungan. Beberapa tahun terakhir tanggungjawab sosial perusahaan atau biasa disebut corporate social responsibility (CSR) menjadi sebuah isu permasalahan utama perkembangan perusahaan. Dalam menjalankan bisnisnya, sebuah perusahaan tidak akan terlepas dari lingkungan dan masyarakat. Perusahaan yang memiliki keinginan untuk tetap bertahan dan memiliki keunggulan kompetitif maka perlu menjadikan CSR sebagai salah satu strategi bisnisnya (Wulandari \& Sudana, 2018). CSR adalah sebuah komitmen perusahaan dengan menitikberatkan sebuah pengembangan etika dan praktik bisnis yang berkesinambungan baik secara ekonomi, sosial maupun lingkungan atau dapat dikatakan sustainable (Irmayanti \& Mimba, 2018).

Pengungkapan (disclosure) merupakan penyajiamn informasi yang diperlukan dalam mencapai sebuah tujuan pelaporan keuangan dan memenuhi kebutuhan pihak lain yang membutuhkan. Adanya peraturan pemerintah mendorong adanya praktik pengungkapan CSR di Indonesia. Dalam penelitian Jayanti dan Husaini (2018) menyatakan pengungkapan sosial di dalam laporan tahunan sebuah perusahaan go public terbukti berpengaruh terhadap tingkat perdagangan saham bagi perusahaan yang masuk kategori perusahaan highprofile, hal ini berarti investor sudah mulai merespon dengan baik informasi sosial yang disajikan perusahaan dalam laporan tahunannya. Semakin luas pengungkapan sosial dalam laporan tahunan yang diungkapkan perusahaan ternyata memberikan pengaruh terhadap jumlah perdagangan saham perusahaan yang menunjukkan lonjakan perdagangan pada seputar publikasi laporan tahunan. Dalam meningkatkan luas pengungkapan CSR, terdapat beberapa hak yang harus diperhatikan yaitu ukuran perusahaan, good corporate governance, dan eco-control.

Ukuran perusahaan dapat mempengaruhi dilakukannya pengungkapan sosial karena semakin besar ukuran perusahaan, semakin besar juga tanggungjawab perusahaan terhadap luas pengungkapan yang harus dilakukan (Dewi \& Ratna Sari, 2019). Sukasih \& Sugiyanto (2017) menjelaskan bahwa besarnya ukuran sebuah perusahaan akan berpengaruh pada banyaknya karyawan, besarnya laba yang didapat, penggunaan sistem yang canggih, produksi barang yang banyak, serta luasnya lingkungan masyarakat yang digunakan, hal ini mengakibatkan banyak pihak harus mendapatkan haknya yaitu pengungkapan yang transparan dari perusahaan. Dewi \& Ratna Sari (2019), Widyastari \& Sari (2018), dan Pradnyani \& Sisdyani (2015) mengangkat topik yang sama daloam penelitiannya menemukan hasil bahwa antara ukuran perusahaan terhadap luas pengungkapan CSR memiliki hubungan yang positif.

Good Corporate Governance yang selanjutnya disebut GCG merupakan seperangkat peraturan dalam rangka pengendalian perusahaan untuk menghasilkan value added bagi para stakeholders karena dengan adanya GCG akan terbentuk pola kerja manajemen yang transparan, bersih, dan profesional (Sudaryati \& Eskadewi, 2012). Indikator GCG biasanya diproksikan dengan ukuran dewan komisaris, komite audit, dan struktur kepemilikan. Ukuran dewan komisaris adalah salah satu komponen GCG yang memiliki hubungan dengan 
CSR yaitu semakin besar jumlah anggota dewan komisaris, maka pengendalian CEO akan semakin mudah serta pengawasan yang dilakukan menjadi lebih efektif (Iswandika, Murtanto, \& Sipayung, 2014). Keberadaan komite audit dalam corporate governance mampu meningkatkan relevansi dan reliabilitas pengungkapan informasi perusahaan, serta berpengaruh terahdap CSR dalam meningkatkan akuntabilitas dan transparansi dalam laporan tahunan salah satunya pengungkapan informasi tanggungjawab sosial (Pradnyani \& Sisdyani, 2015). Kepemilikan manajerial merupakan akumulasi kepemilikan saham perusahaan yang dimiliki oleh direksi, komisaris, ataupun manajemen perusahaan. Adanya kepemilikan manajerial, pengelola dapat melaksanakan aktivitas perusahaan sesuai dengan kepentingannya (Purbawangsa, Solimun, Fernandes, \& Mangesti, 2019).

Eco-control adalah sebuah konsep dalam menyelesaikan sebuah permasalahan lingkungan yang berhubungan dengan dunia bisnis (Henri \& Journeault, 2010). Dampak negatif dari permasalahan lingkungan di luar perusahaan disebut externalities. Dampak externalities yang cukup tinggi berpengaruh dalam kehidupan masyarakat. Hal ini mendorong masyarakat agar perusahaan melakukan eco-control, yaitu mengendalikan dampak externalities sehingga dampak negatif dari aktifitas perusahaan yang ditimbulkannya dapat dikurangi atau diperkecil (Wagner \& Schaltegger, 2004). Sehingga hal ini mendorong adanya pengaruh eco-control terhadap luasnya pengungkapan CSR.

Meski telah ditetapkan peraturan yang menyatakan bahwa suatu badan usaha di Indonesia wajib menjalankan CSR, namun pengungkapan CSR di Indonesia masih bersifat sukarela (voluntary disclosure) (Garas \& ElMassah, 2018). Pengungkapan sukarela yang dimaksud adalah pengungkapan yang bersifat tidak wajib oleh peraturan yang berlaku umum. Perusahaan bebas memilih untuk memberikan informasi akuntansi dan informasi lainnya yang dianggap relevan dan mendukung dalam laporan tahunan perusahaan sesuai dengan batasan manajemen mereka (Fatmawati, Astusti, \& Suhardjanto 2018). Walaupun pengungkapan CSR telah dilakukan namun tidak cukup luas aspek CSR yang diungkapkan perusahaan-perusahaan di Indonesia. Apabila perusahaan telah melakukan pengungkapan CSR tidak hanya internal perusahaan saja yang diuntungkan tetapi juga pihak eksternal lainnya terutama para stakeholders.

Menurut Deegan, Rankin, \& Smith (2009), teori legitimasi meyakini bahwa terdapat "kontrak sosial" antara sebuah dengan lingkungan tempat mereka beroperasi. Kontrak sosial merupakan suatu cara untuk menjelaskan harapan masyarakat tentang bagaimana seharusnya organisasi melaksanakan operasinya. Menurut penelitian Khan, Muttakin, \& Siddiqui (2013) dan Dias, Rodrigues, Craig, \& Neves (2019) teori legitimasi menyatakan bahwa organisasi secara berkelanjutan akan mencari cara untuk mempertahankan operasi mereka dalam batas dan norma yang berlaku di masyarakat. Pengungkapan pelaporan sosial dan lingkungan menjadi solusi perusahaan untuk memperlihatkan kinerja yang baik kepada masyarakat dan investor. Dengan adanya pengungkapan pelaporan sosial, perusahaan akan memperoleh citra dan pengakuan yang baik serta akan memiliki daya tarik dalam investasi di dalam negeri maupun asing (Wickert, 2014). Dalam 
teori legitimasi, perusahaan harus secara berkelanjutan dan konsisten menunjukkan operasi mereka dalam perilaku yang sesuai dengan nilai sosial.

Stakeholders theory menjelaskan bahwa kelangsungan hidup organisasi atau perusahaan bergantung pada dukungan stakeholder yang dapat mempengaruhi aktivitas perusahaan (Ramdhaningsih, 2013). Pengungkapan CSR dapat menggambarkan kemampuan perusahaan dalam menjalin hubungan dengan stakeholders-nya, sehingga semakin luas pengungkapan CSR tersebut maka akan semakin baik dukungan dari stakeholders (Firmansyah \& Surasni, 2020). Teori stakeholder berasumsi bahwa eksistensi perusahaan membutuhkan dukungan dari stakeholder dikarenakan aktivitas perusahaan juga mempertimbangkan persetujuan dari stakeholder. Pengungkapan mengenai masalah sosial dan lingkungan secara sederhana diartikan sebagai sebuah dialog organisasi atau perusahaan dengan stakeholder (Christopher Wickert, Scherer, \& Spence, 2016).

Ukuran perusahaan merupakan salah satu alat ukur untuk menggolongkan besar kecilnya sebuah entitas bisnis. Widyastari \& Sari (2018) dan Sadou, Alom, \& Laluddin, (2017) mengungkapkan dalam penelitiannya bahwa perusahaan besar memiliki banyak aktivitas dan tentu akan memberikan dampak yang besar pada masyarakat sehingga perusahaan besar mendapat tekanan yang lebih untuk mengungkapkan aspek pertanggungjawaban sosialnya secara luas. Selain itu jika dilihat dari pendeketan teori legitimasi mengenai kepentingan terhadap lingkungan maka perusahaan cenderung akan melakukan corporate social responsibility yang lebih luas untuk memberi keyakinan dan jaminan terhadap masyarakat yang berada disekitar aktifitas operasi perusahaan tersebut. Hal inilah yang mengakibatkan ukuran perusahaan akan mendorong luasnya pengungkapan corporate social responsibility di suatu perusahaan (Wickert, 2014).

$\mathrm{H}_{1}$ : Ukuran Perusahaan Berpengaruh Positif terhadap Luas Pengungkapan Corporate Social Responsibility.

Kebutuhan informasi yang transparan dan akuntabel, serta praktik tata kelola perusahaan yang baik (GCG) oleh stakeholders mendorong perusahaan untuk memberikan informasi mengenai aktivitas sosialnya (Pintea, 2015). Jika dilakukan pendekatan teori stakeholder menjelaskan bahwa perusahaan memiliki tanggung jawab informasi kepada stakeholder berkaitan dengan kinerja yang telah dilakukan. Dengan demikian adanya GCG mendorong perusahaan untuk melakukan CSR sebagai bentuk tanggung jawab informasi kepada para pemangku kepentingannya (Fiandrino, Devalle, \& Cantino, 2019). Semakin perusahaan memaksimalkan GCG mereka maka aspek pengungkapan CSR semakin luas, agar informasi yang disampaikan kepada stakeholders semakin lengkap. Dalam hal ini GCG menggunakan indikator ukuran dewan komisaris, komite audit, proporsi komisaris independen, dan kepemilikan manajerial.

$\mathrm{H}_{2}$ : Good Corporate Governance Berpengaruh Positif terhadap Luas Pengungkapan Corporate Social Responsibility.

Tindakan eco-control berpengaruh terhadap environmental performance (kinerja terhadap lingkungan) perusahaan. Artinya jika perusahaan dalam kegiatannya dapat melakukan pengawasan terhadap lingkungan, hal tersebut dapat memaksimalkan environmental performance (Rahmadhani \& Meylani, 2012). Sesuai dengan teori legitimasi bahwa dengan adanya kinerja terhadap lingkungan dalam bentuk CSR maka akan membuat masyarakat memberi respon positif dan 
kepercayaan terhadap perusahaan tersebut. Dengan demikian tindakan eco-control membantu perusahaan dalam menghitung tindakan serta integrasi perhatian lingkungan dalam rutinitas organisasi yang berkaitan dengan luas pengungkapan corporate social responsibility (Henri, Journeault, \& Brousseau, 2017). Dalam hal ini eco-control menggunakan indikator pengukuran kinerja serta anggaran dan insentif.

$\mathrm{H}_{3}$ : Eco-control Berpengaruh Positif terhadap Luas Pengungkapan Corporate Social Responsibility.

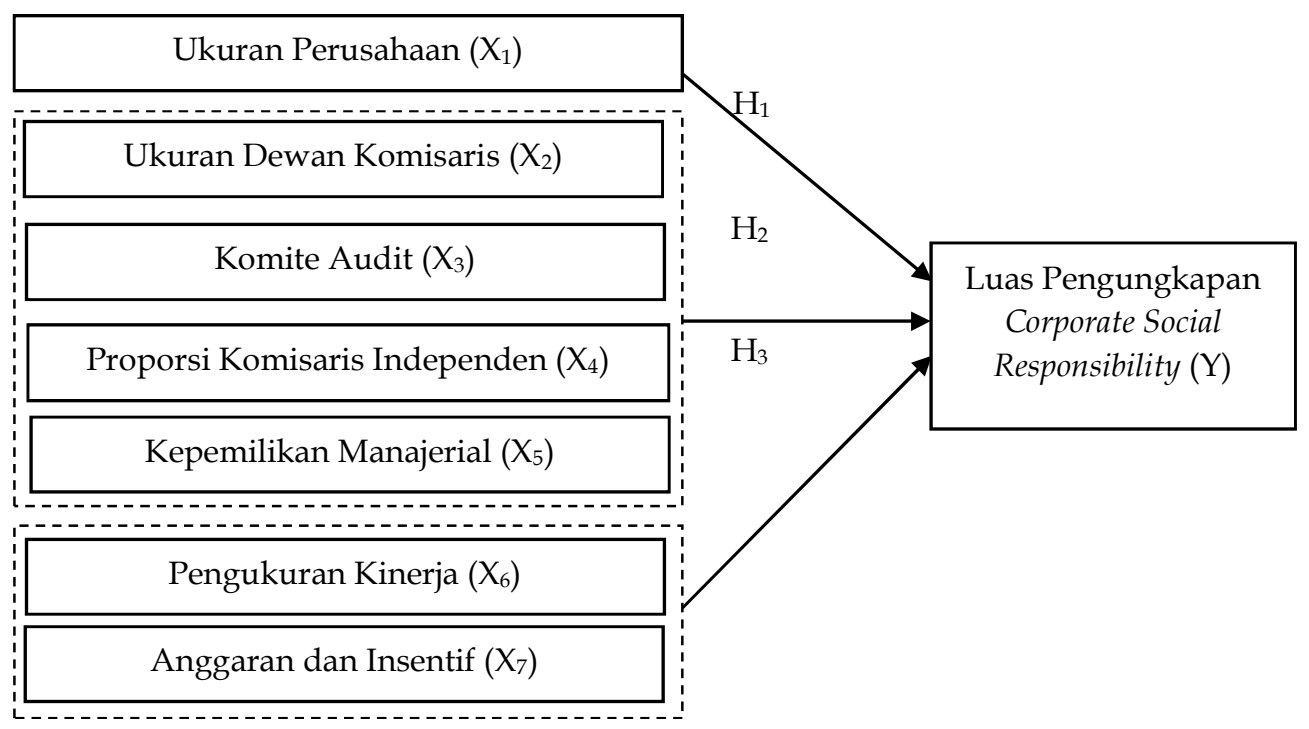

Gambar 1. Model Peneltian

Sumber: Data Penelitian, 2020

\section{METODE PENELITIAN}

Metode penelitian ini menggunakan observasi non participant, artinya peneliti tidak ikut terlibat secara langsung melainkan hanya sebagai seorang pengamat (Sugiyono, 2017). Pengumpulan data diperoleh dari sumber data yang didapatkan melalui pencatatan informasi terhadap data sekunder berupa laporan tahunan dan laporan keberlanjutan masing-masing perusahaan yang diperoleh dari BEI melalui website $w w w . i d x . c o . i d$ dan juga laman resmi perusahaan bersangkutan. Penelitian ini menggunakan pendekatan kuantitatif berbentuk asosiatif karena menguji dua variabel atau lebih (Sugiyono, 2017). Penelitian ini dilakukan untuk mengetahui pengaruh ukuran perusahaan, good corporate governance, dan ecocontrol terhadap luas pengungkapan corporate social responsibility. Objek dalam penelitian ini luas pengungkapan corporate social responsibility pada perusahaan penghasil bahan baku pertambangan yang terdaftar dalam Bursa Efek Indonesia (BEI) tahun 2017-2019.

Berdasarkan penelitian ini, yang menjadi sasaran populasi adalah semua perusahaan pengahasil bahan baku yang terdaftar di BEI selama periode 20172019 serta termasuk dalam sektor perusahaan penghasil bahan baku. Sampel adalah sebagian dari populasi. Sampel terdiri atas jumlah anggota yang dipilih dari populasi (Sugiyono, 2017). Sampel dalam penelitian ini berjumlah 11 
perusahaan penghasil bahan baku sub sektor pertambangan. Maka jumlah observasi yang digunakan sebanyak 33 observasian. Sampel didapatkan dengan menggunakan teknik purposive sampling. Dengan kriteria yang pertama, perusahaan yang bergerak dalam pertambangan di BEI selama tahun pengamatan yaitu tahun 2017-2019. Kedua, mempublikasikan laporan tahunan secara terusmenerus selama periode tahun pengamatan yaitu tahun 2017-2019. Ketiga, mempublikasikan laporan keberlanjutan secara terus menerus selama periode tahun pengamatan yaitu tahun 2017-2019

Variabel bebas dalam penelitian ini adalah ukuran perusahaan $\left(\mathrm{X}_{1}\right)$, ukuran dewan komisaris $\left(X_{2}\right)$, komite audit $\left(X_{3}\right)$, proporsi komisaris independen $\left(X_{4}\right)$, kepemilikan manajerial $\left(X_{5}\right)$, pengukuran kinerja $\left(X_{6}\right)$, serta anggaran dan insentif $\left(X_{7}\right)$. Dalam penelitian ini yang menjadi variabel terikat adalah luas pengungkapan corporate social responsibility (Y).

Ukuran perusahaan adalah skala perusahaan yang dilihat pada total aset pada akhir tahun (Prasetyorini, 2013). Ukuran perusahaan biasanya dikelompokan menjadi perusahaan besar, perusahaan sedang, dan perusahaan kecil. Total aset perusahaan yang bernilai besar dapat disederhanakan dan ditransformasikan ke dalam logaritma natural (Ghozali, 2018).

Dewan komisaris merupakan inti dari corporate governance yang ditugaskan untuk menjamin pelaksanaan strategi perusahaan, mengawasi manajemen dalam mengelola perusahaan, dan mewajibkan terlaksananya akuntabilitas (Rashid, 2018). Ukuran dewan komisaris dilihat dari jumlah anggota dewan komisaris yang terdapat pada perusahaan (Sukasih \& Sugiyanto, 2017). Komite audit merupakan komite yang dibentuk oleh dewan komisaris, yang bertugas untuk membantu dewan komisaris dalam melaksanakan tugasnya. Komite audit diukur dengan menjumlahkan seluruh anggota komite audit yang terdapat di perusahaan (Sukasih \& Sugiyanto, 2017). Komisaris independen di dalam perusahaan merupakan suatu pihak yang tidak mempunyai kepentingan bisnis maupun kekeluargaan dengan perusahaan, pemegang saham pengendali, anggota direksi, dan anggota komisaris (Sukasih \& Sugiyanto, 2017). Proporsi komisaris independen diukur dari presentase jumlah anggota komisaris independen dengan jumlah seluruh anggota dewan komisaris yang ada di perusahaan (Iswandika et al., 2014). Ukuran struktur kepemilikan yang digunakan dalam penelitian ini adalah kepemilikan saham manajerial. Kepemilikan saham adalah salah satu hal penting yang mampu berpengaruh terhadap pengambilan keputusan perusahaan. Kepemilikan saham manajerial diukur melalui persentase kepemilikan saham dewan direksi dan komisaris dalam perusahaan (Iswandika et al., 2014).

Eco-control adalah metode kontrol strategis untuk manajemen lingkungan (Henri \& Journeault, 2010). Sebagai sistem kontrol manajemen, mengontrol lingkungan telah menarik perhatian dalam beberapa tahun terakhir sebagai sarana untuk mengarahkan strategi lingkungan di seluruh perusahaan. Indikator yang digunakan dalam pengukuran eco-control salah satunya penggunaan pengukuran kinerja, (Henri \& Journeault, 2010). Pengukuran kinerja dihitung dengan menggunakan Return on Assets (ROA). ROA merupakan kemampuan perusahaan menghasilkan tingkat pengembalian aset dengan laba yang diperoleh. ROA akan dihitung dengan mencari rata-ratanya, apabila nilai ROA perusahaan kurang dari rata-rata maka akan diberikan nilai 0 (nol) bagi perusahaan tersebut dan jika lebih 
dari rata-rata maka akan diberi nilai 1 (satu). Penilaian tersebut diberikan karena melalui rata-rata ROA dari beberapa perusahaan akan menjadi standar pengukuran kinerja, dengan demikian nilai ROA lebih dari standar akan dikategorikan lebih baik dari ROA yang berada kurang dari standar (Rahmadhani \& Meylani, 2012). Apabila ROA perusahaan berada lebih dari rata-rata yang telah ditentukan maka perusahaan tersebut telah menjalankan kinerjanya dengan baik, sehingga akan berpengaruh terhadap eco-control. ROA dihitung dengan persentase laba bersih perusahaan dengan total aset perusahaan.

Indikator lainnya dalam eco-control yaitu anggaran dan insentif (Journeault, De Rongé, \& Henri, 2016). Anggaran adalah perkiraan pendapatan dan pengeluran selama periode waktu tertentu di masa depan dan biasanya disusun dan dievaluasi kembali secara berkala. Sedangkan insentif merupakan sebuah kompensasi khusus dari perusahaan untuk karyawannya di luar gaji utamanya. Hal tersebut untuk memotivasi karyawan agar lebih giat dalam bekerja dan berusaha memperbaiki prestasi kerjanya ke arah yang positif di perusahaan. Dalam eco-control pengkuran anggaran dan insentif dilihat pada annual report. Jika perusahaan mengungkapkan anggaran pada pengeluaran dan investasi terhadap lingkungan serta memberikan insetif kepada karyawannya maka diberi nilai 1 (satu) pada masing-masing item dan jika tidak diungkapkan diberi nilai 0 (nol) (Rahmadhani \& Meylani, 2012). Sehingga apabila suatu perusahaan telah mengalokasikan anggaran yang berhubungan dengan aktivitas CSR dan telah memberikan insentif kepada karyawan hal ini berarti perusahaan tersebut telah mendukung kegiatan yang berhubungan dengan CSR sehingga dapat dikategorikan memiliki eco-control dengan baik.

Pengungkapan corporate social responsibility (CSR) adalah mekanisme yang digunakan oleh perusahaan untuk berkomunikasi dengan stakeholder dan digunakan untuk memberikan keuntungan atau memperbaiki legitimasi bagi perusahaan (Wedayanti \& Wirajaya, 2018). Pengukuran pengungkapan CSR dalam penelitian ini menggunakan Corporate Social Responsibility Index (CSRI) dengan standar pelaporan internasional (sustainability reporting guidelines G-4). Standar tersebut dikeluarkan oleh Global Reporting Initiative (GRI) di tahun 2013 yang menyatakan bahwa terdapat 91 item yang harus diungkapkan dalam CSR (Pradana \& Astika, 2019). CSRI digunakan untuk mengetahui seberapa luas pengungkapan CSR yang dilakukan perusahaan. Perhitungan indeks yaitu dengan cara membagi jumlah item yang diungkapkan dengan jumlah item keseluruhan (Reverte, Gomez, \& Cegarra, 2016).

Teknik analisis data dalam penelitian ini menggunakan analisis regresi linier berganda dengan melakukan uji asumsi klasik terlebih dahulu yaitu uji normalitas, heterokedastisitas, uji autokorelasi, dan uji multikolinearitas. Serta melakukan uji koefisien determinasi (Adjusted $\mathrm{R}^{2}$ ), uji kelayakan model ( $\mathrm{F}$ test), dan uji hipotesis (t-test). Adapun persamaan umum regresi berganda, sebagai berikut.

$Y=\alpha+\beta_{1} X_{1}+\beta_{2} X_{2}+\beta_{3} X_{3}+\beta_{4} X_{4}+\beta_{5} X_{5}+\beta_{6} X_{6}+\beta_{7} X_{7}+\varepsilon$

\section{HASIL DAN PEMBAHASAN}

Sampel penelitian yang digunakan dalam peneltian ini adalah perusahaan pertambangan yang terdaftar di BEI dan mempublikasikan laporan tahunan dan 
laporan keberlanjutan secara berturut-turut selama periode pengamatan yaitu tahun 2017-2019.

Tabel 1. Hasil Seleksi Pemilihan Sampel

\begin{tabular}{|c|c|c|c|}
\hline & Keterangan & \multirow{2}{*}{$\begin{array}{l}\text { Jumlah } \\
70\end{array}$} \\
\hline Populasi & & $\begin{array}{l}\text { Perusahaan pengahasil bahan baku yang } \\
\text { terdaftar di BEI }\end{array}$ & \\
\hline \multirow[t]{3}{*}{ Kriteria } & 1. & $\begin{array}{l}\text { Perusahaan yang tidak bergerak dalam } \\
\text { pertambangan di BEI selama tahun pengamatan }\end{array}$ & (21) \\
\hline & 2. & $\begin{array}{l}\text { Perusahaan yang tidak mempublikasikan } \\
\text { laporan tahunan selama periode tahun } \\
\text { pengamatan }\end{array}$ & (9) \\
\hline & 3. & $\begin{array}{l}\text { Perusahaan yang tidak mempublikasikan } \\
\text { laporan keberlanjutan selama periode tahun } \\
\text { pengamatan }\end{array}$ & (29) \\
\hline \multicolumn{3}{|c|}{ Total perusahaan yang dijadikan sampel } & 11 \\
\hline \multicolumn{3}{|c|}{ Total sampel selama tahun $2017-2019$} & 33 \\
\hline
\end{tabular}

Sumber: Data Penelitian, 2020

Statistik deskriptif digunakan sebagai uji yang menjelaskan deskripsi suatu data melalui rata-rata (mean), standar deviasi (standard deviation), dan maksimumminimum. Nilai rata-rata menjelaskan perkiraan besar rata-rata populasi dari sampel. Standar deviasi menjelaskan atau menilai disperse rata-rata dari sampel. Maksimum-minimum menjelaskan nilai maksimum dan minimum dari populasi.

Tabel 2. Hasil Statistik Deskriptif

\begin{tabular}{lrrrrr}
\hline \multicolumn{1}{c}{ Variabel } & $N$ & Minimum & Maximum & Mean & $\begin{array}{c}\text { Std. } \\
\text { Deviation }\end{array}$ \\
\hline Luas Pengungkapan CSR & 33 & 0,055 & 0,835 & 0,315 & 0,171 \\
Ukuran Perusahaan & 33 & 29,211 & 31,678 & 30,586 & 0,742 \\
Ukuran Dewan Komisaris & 33 & 3,000 & 10,000 & 5,727 & 1,526 \\
Komite Audit & 33 & 2,000 & 5,000 & 3,394 & 0,659 \\
Proporsi Komisaris & 33 & 0,167 & 0,500 & 0,366 & 0,073 \\
Independen & 33 & 0,000 & 0,194 & 0,195 & 0,443 \\
Kepemilikan Manajerial & 33 & 0,000 & 1,000 & 0,333 & 0,479 \\
Pengukuran Kinerja & 33 & 0,000 & 1,000 & 0,848 & 0,364 \\
Anggaran dan Insentif & & & & & \\
\hline
\end{tabular}

Sumber: Data Penelitian, 2020

Variabel luas pengungkapan CSR dalam penelitian ini diukur menggunakan CSRI berdasarkan sustainability reporting guidelines G-4 oleh GRI. Berdasarkan Tabel 2, luas pengungkapan CSR menunjukan nilai rata-rata sebesar 0,315, hal ini menunjukkan ada kecenderungan mendekati nilai minimum. Hal tersebut berarti perusahaan memiliki tingkat luas pengungkapan CSR rendah. Nilai standar deviasi luas pengungkapan CSR sebanyak 0,171, kurang dari nilai rata-rata, hal ini berarti sebaran data luas pengungkapan CSR rentang data yang satu dengan lainnya tidak tergolong tinggi (sudah merata).

Variabel ukuran perusahaan yang digunakan dalam penelitian ini diukur dengan logaritma natural dari jumlah total aset perusahaan. Berdasarkan Tabel 2, ukuran perusahaan menunjukan nilai rata-rata sebesar 30,586, hal ini menunjukkan ada kecenderungan mendekati nilai minimum. Artinya perusahaan memiliki tingkat ukuran perusahaan rendah. Nilai standar deviasi ukuran perusahaan sebesar 0,743 , lebih kecil daripada nilai rata-rata, hal ini berarti 
sebaran data ukuran perusahaan rentang data yang satu dengan lainnya tidak tergolong tinggi (sudah merata).

Variabel ukuran dewan komisaris dalam penelitian ini diukur menggunakan jumlah dewan komisaris. Bedasarkan Tabel 2, ukuran dewan komisaris menunjukan nilai rata-rata sebesar 5,727, hal ini menunjukkan ada kecenderungan mendekati nilai minimum. Hal tersebut menyatakan bahwa ratarata perusahaan mempunyai tingkat ukuran dewan komisaris rendah. Nilai standar deviasi ukuran dewan komisaris sebesar 1,526, lebih kecil daripada nilai rata-rata, hal ini berarti sebaran data ukuran dewan komisaris rentang data yang satu dengan lainnya tidak tergolong tinggi (sudah merata).

Variabel komite audit dalam penelitian ini diukur menggunakan jumlah komite audit. Berdasarkan Tabel 2, komite audit menunjukan nilai rata-rata sebesar 3,394, hal ini menunjukkan ada kecenderungan mendekati nilai maksimum. Hal ini menjelaskan rata-rata perusaaan memiliki tingkat komite audit tinggi. Nilai standar deviasi ukuran dewan komisaris sebanyak 0,6585 , atau kurang dari nilai rata-rata, hal ini berarti sebaran data komite audit rentang data yang satu dengan lainnya tidak tergolong tinggi (sudah merata).

Variabel proporsi komisaris independen dalam penelitian ini diukur menggunakan perbandingan antara komisaris independen dengan dewan komisaris. Berdasarkan Tabel 2, proporsi komisaris independen menunjukan nilai rata-rata sebesar 0,366 , hal ini menunjukkan ada kecenderungan mendekati nilai minimum. Hal ini menjelaskan rata-rata perusaaan memiliki tingkat proporsi komisaris independen rendah. Nilai standar deviasi ukuran dewan komisaris sebesar 0,073, lebih kecil daripada nilai rata-rata, hal ini menunjukkan sebaran data proporsi komisaris rentang data yang satu dengan lainnya tidak tergolong tinggi (sudah merata).

Variabel kepemilikan manajerial dalam penelitian ini diukur menggunakan jumlah saham dewan komisaris, dewan direksi dan manajer. Berdasarkan Tabel 2, kepemilikan manajerial menunjukan nilai rata-rata sebesar 0,020, hal ini menunjukkan ada kecenderungan mendekati nilai minimum. Hal ini menjelaskan rata-rata perusaaan memiliki tingkat kepemilikan manajerial rendah. Nilai standar deviasi kepemilikan manajerial sebanyak 0,044, lebih kecil daripada nilai rata-rata, hal ini berarti sebaran data kepemilikan manajerial rentang data yang satu dan lainnya tidak tergolong tinggi (sudah merata).

Variabel pengukuran kinerja dalam penelitian ini diukur menggunakan ROA. Berdasarkan Tabel 2, pengukuran kinerja menunjukan nilai rata-rata sebesar 0,3333, hal ini menunjukkan ada kecenderungan yang mendekati nilai minimum. Hal ini berarti rata-rata perusaaan memiliki tingkat ukuran pengkuran kinerja rendah. Nilai standar deviasi pengukuran kinerja sebanyak 0,479, lebih kecil daripada nilai rata-rata, artinya sebaran data pengukuran kinerja rentang data yang satu dengan lainnya tidak tergolong tinggi (sudah merata).

Variabel anggaran dan insentif dalam penelitian ini diukur menggunakan anggaran dan insentif yang dikeluarkan untuk kepentingan CSR. Berdasarkan Tabel 2, anggaran dan insentif menunjukan nilai rata-rata sebanyak 0,848 , hal ini menunjukkan ada kecenderungan yang mendekati nilai maksimum. Artinya ratarata perusaaan memiliki tingkat ukuran anggaran dan insentif tinggi. Nilai standar deviasi anggaran dan insentif sebanyak 0,364, lebih kecil daripada nilai 
rata-rata, artinya sebaran data anggaran dan insentif rentang data yang satu dengan lainnya tidak tergolong tinggi (sudah merata).

Tabel 3. Hasil Uji Normalitas

\begin{tabular}{|c|c|}
\hline Kolomogorov-Smirnov Z & Unstandardized Residual \\
\hline $\mathrm{N}$ & 33 \\
\hline Asymp.Sig (2-tailed) & 0,200 \\
\hline
\end{tabular}

Sumber: Data Penelitian, 2020

Data yang digunakan dalam penelitian ini akan memiliki distribusi normal dengan syarat nilai Asymp.Sig (2-tailed) lebih dari a = 0,05. Tabel 3, menyatakan bahwa nilai Asymp.Sig (2-tailed) di model persamaan penelitian yang diuji memiliki nilai 0,200 yaitu lebih besar dari 0,05 . Artinya data dalam penelitian ini sudah memiliki distribusi normal.

Tabel 4. Hasil Uji Multikolonearitas

\begin{tabular}{lcc}
\hline \multicolumn{1}{c}{ Variabel } & Tolerance & VIF \\
\hline Ukuran Perusahaan $\left(\mathrm{X}_{1}\right)$ & 0,902 & 1,109 \\
Ukuran Dewan Komisaris $\left(\mathrm{X}_{2}\right)$ & 0,952 & 1,051 \\
Komite Audit $\left(\mathrm{X}_{3}\right)$ & 0,839 & 1,192 \\
Proporsi Komisaris Independen $\left(\mathrm{X}_{4}\right)$ & 0,864 & 1,158 \\
Kepemilikan Manajerial $\left(\mathrm{X}_{5}\right)$ & 0,898 & 1,114 \\
Pengukuran Kinerja $\left(\mathrm{X}_{6}\right)$ & 0,811 & 1,233 \\
Anggaran dan Insentif $\left(\mathrm{X}_{7}\right)$ & 0,781 & 1,281 \\
\hline
\end{tabular}

Sumber: Data Penelitian, 2020

Pada Tabel 4, dari hasil perhitungan SPSS menunjukkan variabel bebas tidak saling berkorelasi dalam model regresi. Nilai VIF yang diperoleh dari variabel bebas yang digunakan lebih kecil dari wo dan nilai tolerance lebih besar dari 0,1, artinya tidak terdapat multikolinearitas dalam model regresi di penelitian antara variabel bebas.

Tabel 5. Hasil Uji Autokorelasi

\begin{tabular}{rrrrrrr}
\hline Model & $R$ & $R$ Square & $\begin{array}{c}\text { Adjusted } R \\
\text { Square }\end{array}$ & $\begin{array}{c}\text { Std. Error of the } \\
\text { Estimate }\end{array}$ & $\begin{array}{c}\text { Durbin- } \\
\text { Watson }\end{array}$ \\
\hline 1 & 0,843 & 0,710 & 0,629 & 0,10437 & 1,998
\end{tabular}

Sumber: Data Penelitian, 2020

Berdasarkan hasil uji autokorelasi menggunakan uji Durbin-Watson sesuai dengan Tabel 5, lebih dari nilai DW yang didapat sebesar 1,998. berdasarkan jumlah $\mathrm{n}=33$ dan $\mathrm{k}=7$, maka diperoleh nilai $\mathrm{dL}=0,9940$ dan $\mathrm{dU}=1,9906$ hal tersebut juga menghasilkan nilai $4-\mathrm{dL}=3,0060$ dan nilai $4-\mathrm{dU}=2,0094$ maka dapat dirumuskan kriteria dU $<$ DW $<4$-dU yaitu $(1,9906<1,998<2,0094)$. Hal ini menunjukan bahwa tidak terdapat gejala atau masalah autokorelasi.

Tabel 6. Hasil Uji Heterokedastisitas

\begin{tabular}{lcc}
\hline \multicolumn{1}{c}{ Variabel } & Sig. & Keterangan \\
\hline Ukuran Perusahaan $\left(X_{1}\right)$ & 0,978 & Bebas heterokedastisitas \\
Ukuran Dewan Komisaris $\left(X_{2}\right)$ & 0,391 & Bebas heterokedastisitas \\
Komite Audit $\left(X_{3}\right)$ & 0,388 & Bebas heterokedastisitas \\
Proporsi Komisaris Independen $\left(X_{4}\right)$ & 0,155 & Bebas heterokedastisitas \\
Kepemilikan Manajerial $\left(X_{5}\right)$ & 0,524 & Bebas heterokedastisitas \\
Pengukuran Kinerja $\left(X_{6}\right)$ & 0,843 & Bebas heterokedastisitas \\
Anggaran dan Insentif $\left(X_{7}\right)$ & 0,658 & Bebas heterokedastisitas \\
\hline
\end{tabular}

Sumber: Data Penelitian, 2020 
Tabel 6, menyatakan signifikasi lebih dari tingkat kepercayaan 0,05. Artinya dapat ditarik kesimpulan bahwa tidak terdapat gejala heteroskedastisitas dari data penelitian yang menggunakan variabel dependen luas pengungkapan CSR.

Tabel 7. Hasil Analisis Regresi Linear Berganda dan Hasil Koefisien Determinasi

\begin{tabular}{|c|c|c|c|c|c|c|}
\hline & \multirow[t]{2}{*}{ Model } & \multicolumn{2}{|c|}{$\begin{array}{c}\text { Unstandardised } \\
\text { Coefficients }\end{array}$} & \multirow{2}{*}{$\begin{array}{c}\text { Standardized } \\
\text { Coefficients }\end{array}$} & \multirow[t]{2}{*}{$t$} & \multirow[t]{2}{*}{ Sig. } \\
\hline & & $B$ & Std. Error & & & \\
\hline \multirow[t]{8}{*}{1} & (Constant) & 1,501 & 0,210 & & 7,162 & 0,000 \\
\hline & $X_{1}$ & 0,023 & 0,006 & 0,456 & 4,021 & 0,000 \\
\hline & $X_{2}$ & 0,017 & 0,009 & 0,204 & 1,847 & 0,047 \\
\hline & $X_{3}$ & 0,057 & 0,014 & 0,481 & 4,093 & 0,000 \\
\hline & $X_{4}$ & 0,838 & 0,222 & 0,437 & 3,768 & 0,001 \\
\hline & $X_{5}$ & 0,561 & 0,277 & 0,230 & 2,024 & 0,044 \\
\hline & $X_{6}$ & 0,235 & 0,003 & 0,003 & 0,028 & 0,038 \\
\hline & $X_{7}$ & 0,170 & 0,047 & 0,437 & 3,584 & 0,001 \\
\hline & $d R$ Square & : 0,629 & & & & \\
\hline
\end{tabular}

Sumber: Data Penelitian, 2020

Dari hasil analisis regresi linier berganda pada Tabel 7, dapat dibuat persamaan sebagai berikut.

$$
\mathrm{Y}=1,501+0,023 \mathrm{X}_{1}+0,017 \mathrm{X}_{2}+0,057 \mathrm{X}_{3}+0,838 \mathrm{X}_{4}+0,561 \mathrm{X}_{5}+0,235 \mathrm{X}_{6}+0,170 \mathrm{X}_{7}+\varepsilon
$$

Tabel 7, menunjukan nilai Adjusted $\mathrm{R}^{2}$ adalah 0,629 , artinya bahwa variasi variabel independen dapat menjelaskan variasi variabel dependen sebesar 62,9 persen, sedangkan sisanya yaitu sebanyak 37,1 persen dijelaskan oleh variabelvariabel yang lain diluar variabel independen.

Tabel 8. Hasil Uji Kelayakan Model (F)

\begin{tabular}{|c|c|c|c|c|c|c|}
\hline & Model & $\begin{array}{l}\text { Sum of } \\
\text { Squares }\end{array}$ & $d f$ & Mean Square & $F$ & Sig \\
\hline \multirow[t]{3}{*}{1} & Regression & 0,667 & 7 & 0,095 & 8,747 & 0,000 \\
\hline & Residual & 0,272 & 25 & 0,011 & & \\
\hline & Total & 0,939 & 32 & & & \\
\hline
\end{tabular}

Sumber: Data Penelitian, 2020

Tabel 8, menunjukan jumlah nilai $\mathrm{F}_{\text {hitung }}$ sebesar 8,747 memiliki signifikansi F sebesar 0,000 kurang dari nilai $a=0,05$ berarti bahwa ukuran perusahaan, good corporate governance, dan eco-control secara simultan berpengaruh terhadap luas pengungkapan CSR serta model regresi linier berganda memiliki kelayakan untuk digunakan sebagai alat analisis di penelitian ini.

Tabel 9. Hasil Uji Hipotesis

\begin{tabular}{lrr}
\hline \multicolumn{1}{c}{ Model } & $\beta$ & Sig. \\
\hline (Constant) & 1,501 & 0,000 \\
Ukuran Perusahaan $\left(X_{1}\right)$ & 0,023 & 0,000 \\
Ukuran Dewan Komisaris $\left(X_{2}\right)$ & 0,017 & 0,047 \\
Komite Audit $\left(X_{3}\right)$ & 0,057 & 0,000 \\
Proporsi Komisaris Independen $\left(X_{4}\right)$ & 0,838 & 0,001 \\
Kepemilikan Manajerial $\left(X_{5}\right)$ & 0,561 & 0,044 \\
Return on Assets $\left(X_{6}\right)$ & 0,235 & 0,038 \\
Anggaran dan Insentif $\left(X_{7}\right)$ & 0,170 & 0,001 \\
\hline
\end{tabular}

Sumber: Data Penelitian, 2020 
Berdasarkan Tabel 9, nilai signifikasi $X_{1}$ yaitu 0,000 kurang dari 0,05, menunjukan variabel berpengaruh positif terhadap $\mathrm{Y}\left(\mathrm{H}_{1}\right.$ diterima). Nilai signifikasi $X_{2}$ yaitu 0,047 kurang dari 0,05 , menunjukan variabel berpengaruh positif terhadap $\mathrm{Y}\left(\mathrm{H}_{2}\right.$ diterima). Nilai signifikasi $\mathrm{X}_{3}$ yaitu 0,000 kurang dari 0,05 , menunjukan variabel berpengaruh positif terhadap $\mathrm{Y}\left(\mathrm{H}_{2}\right.$ diterima). Nilai signifikasi $\mathrm{X}_{4}$ yaitu 0,001 kurang dari 0,05, menunjukan variabel berpengaruh positif terhadap $Y\left(\mathrm{H}_{2}\right.$ diterima). Nilai signifikasi $\mathrm{X}_{5}$ yaitu 0,044 kurang dari 0,05 , menunjukan variabel berpengaruh positif terhadap $\mathrm{Y}\left(\mathrm{H}_{2}\right.$ diterima). Nilai signifikasi $\mathrm{X}_{6}$ yaitu 0,038 kurang dari 0,05, menunjukan variabel berpengaruh positif terhadap $Y\left(\mathrm{H}_{3}\right.$ diterima). Nilai signifikasi $\mathrm{X}_{7}$ yaitu 0,001 kurang dari 0,05 , menunjukan variabel berpengaruh positif terhadap $\mathrm{Y}\left(\mathrm{H}_{3}\right.$ diterima $)$.

\section{SIMPULAN}

Ukuran perusahaan berpengaruh positif pada luas pengungkapan CSR. Ukuran perusahaan yang besar biasanya memiliki aktivitas yang lebih banyak sehingga biasanya lebih mampu untuk mengungkapkan CSR secara luas. Good corporate governance berpengaruh positif pada luas pengungkapan CSR. Hal tersebut menunjukkan bahwa semakin tinggi ukuran dewan komisaris dan proporsi komisaris independen maka monitoring yang dilakukan dalam perusahaan akan semakin mudah dan efektif. Eco-control berpengaruh positif terhadap luas pengungkapan CSR. Pengukuran kinerja dapat dilihat dari ROA yang berkaitan dengan lingkungan sehingga hal tersebut mempengaruhi luas pengungkapan CSR.

Penelitian ini hanya terdapat keterbatasan di aspek pengukuran variable ecocontrol, dalam melakukan pengukuran varibel tersebut menggunakan indikator ROA yang belum kuat korelasinya. Tidak kuatnya indikator ROA tersebut karena tingkat pengembalian yang terjadi di sebuah perusahaan tidak selalu dipengaruhi oleh eco-control saja, tetapi bisa dipengaruhi oleh aktivitas operasi perusahaan. Sehingga, untuk peneliti selanjutnya dapat menggunakan indikator lain yang lebih kuat korelasinya untuk mengukur eco-control.

\section{REFERENSI}

Deegan, Rankin, \& Smith. (2009). An Examination of Corporate Social Disclosures in The Annual reports of Indonesian Listed Companies. Asia Pacific Centre for Environmental Accountability Journal, 15(3), 312-343.

Dewi, N. K. A. T., \& Ratna Sari, M. M. (2019). Pengaruh Ukuran Perusahaan, Leverage, dan Profitabilitas Pada CSR Disclosure. E-Jurnal Akuntansi, 27, 1956. https:// doi.org/10.24843/eja.2019.v27.i03.p12

Dias, A., Rodrigues, L. L., Craig, R., \& Neves, M. E. (2019). Corporate social responsibility disclosure in small and medium-sized entities and large companies. Social Responsibility Journal, 15(2), 137-154. https://doi.org/10.1108/SRJ-05-2017-0090

Fatmawati, R., Astuti, D. W., \& Suhardjanto, D. (2018). Peran Corporate Governance dalam Meningkatkan Voluntary Disclosure. Jurnal Akuntansi Multiparadigma, 9(1), 57-69. https://doi.org/10.18202/jamal.2018.04.9004

Fiandrino, S., Devalle, A., \& Cantino, V. (2019). Corporate governance and financial performance for engaging socially and environmentally responsible 
practices. Social Responsibility Journal, 15(2), 171-185. https:// doi.org/10.1108/SRJ-12-2017-0276

Firmansyah, D., \& Surasni, N. K. (2020). Pengaruh CSR Terhadap Nilai Perusahaan Dengan Good Corporate Governance Dan Ukuran Perusahaan Sebagai Variabel Pemoderasi. E-Jurnal Akuntansi Universitas Udayana, 30(1), 163-178.

Garas, S., \& ElMassah, S. (2018). Corporate governance and corporate social responsibility disclosures: The case of GCC countries. Critical Perspectives on International Business, 14(1), 2-26. https://doi.org/10.1108/cpoib-10-20160042

Ghozali, I. (2018). Aplikasi Analisis Multivariate dengan Program IBM SPSS 25. Semarang: Badan Penerbit Universitas Diponegoro.

Henri, Jean François, \& Journeault, M. (2010). Eco-control: The influence of management control systems on environmental and economic performance. Accounting, Organizations and Society, 35(1), 63-80. https://doi.org/10.1016/j.aos.2009.02.001

Henri, Jean Francois, Journeault, M., \& Brousseau, C. (2017). Eco-control change and environmental performance: A longitudinal perspective. Journal of Accounting and Organizational Change, 13(2), 188-215. https://doi.org/10.1108/JAOC-04-2016-0023

Irmayanti, K. N. D., \& Mimba, N. P. S. H. (2018). Pengaruh Profitabilitas, Leverage dan Kepemilikan Asing pada Pengungkapan Corporate Social Responsibility dengan Ukuran Perusahaan Sebagai Variabel Moderasi. E-Jurnal Akuntansi, 23, 1932. https:// doi.org/10.24843/eja.2018.v23.i03.p12

Iswandika, R., Murtanto, M., \& Sipayung, E. (2014). Pengaruh Kinerja Keuangan, Corporate Governance, Dan Kualitas Audit Terhadap Pengungkapan Corporate Social Responsibility. Jurnal Akuntansi Trisakti, 1(2), 1. https://doi.org/10.25105/jat.v1i2.4804

Jayanti, K. R., \& Husaini, A. (2018). Pengaruh Good Corporate Governance dan Profitabilitas Terhadap Pengungkapan Corporate Social Responsibility (Studi pada Perusahaan Sektor Pertambangan yang Terdaftar di Bursa Efek Indonesia Periode 2015-2016). Jurnal Administrasi Bisnis (JAB), 59(1), 16-22. https:// doi.org/998-3068-1-pb.pdf

Journeault, M., De Rongé, Y., \& Henri, J. F. (2016). Levers of eco-control and competitive environmental strategy. British Accounting Review, 48(3), 316-340. https://doi.org/10.1016/j.bar.2016.06.001

Khan, A., Muttakin, M., \& Siddiqui, J. (2013). Corporate governance and corporate social responsibility disclosures: evidence from an emerging economy. Journal Bussines Ethics, 114(2), 207-223.

Pintea, M. (2015). The relationship between corporate governance and corporate social responsibilities. Virgil Madgearu Review of Economic Studies and Research, 1,91-108.

Pradana, R., \& Astika, I. B. P. (2019). Pengaruh Ukuran Perusahaan, Penerapan Good Corporate Governance, dan Pengungkapan Corporate Social Responsibility pada Nilai Perusahaan. E-Jurnal Akuntansi, 28(3), 1920. https://doi.org/10.24843/eja.2019.v28.i03.p18

Pradnyani, I., \& Sisdyani, E. (2015). Pengaruh Ukuran Perusahaan, Profitabilitas, Leverage, Dan Ukuran Dewan Komisaris Pada Pengungkapan Tanggung 
Jawab Sosial Perusahaan. E-Jurnal Akuntansi, 11(2), 384-397.

Prasetyorini, B. F. (2013). Pengaruh Ukuran Perusahaan, Leverage, Price Earning Ratio dan Profitabilitas terhadap Nilai Perusahaan. Jurnal Ilmu Manajemen (JIM), 1(1).

Purbawangsa, I. B. A., Solimun, S., Fernandes, A. A. R., \& Mangesti, S. R. (2019). Corporate governance, corporate profitability toward corporate social responsibility disclosure and corporate value (comparative study in Indonesia, China and India stock exchange in 2013-2016). Social Responsibility Journal, 16(7), 983-999. https:// doi.org/10.1108/SRJ-08-2017-0160

Rahmadhani, S., \& Meylani, D. (2012). Pengaruh Eco-Control Terhadap CSR Disclosure dan Financial Performance dengan Environmental Performace Sebagai Variabel Intervening. Dinamika Ekonomi Dan Bisnis, 13(1), 32-46.

Ramdhaningsih, A. (2013). Pengaruh Indikator Good Corporate Governance Dan Profitabilitas Pada Pengungkapan Corporate Social Responsibility. E-Jurnal Akuntansi, 3(2), 368-386.

Rashid, A. (2018). The influence of corporate governance practices on corporate social responsibility reporting. Social Responsibility Journal, 14(1), 20-39.

Reverte, C., Gomez, M., \& Cegarra, N. (2016). The influence of corporate social responsibility practices on organizational performance: evidence from ecoresponsible spanish firms. Journal of Cleaner Production, 112(4), 2870-2884.

Sadou, A., Alom, F., \& Laluddin, H. (2017). Corporate social responsibility disclosures in Malaysia: Evidence from large companies. Social Responsibility Journal, 13(1), 177-202. https:/ / doi.org/10.1108/SRJ-06-2016-0104

Sudaryati, D., \& Eskadewi, Y. (2012). Pengaruh Corporate Governance Terhadap Tingkat Pengungkapan Corporate Social Responsibility Di Bank Syariah. Jurnal Ekonomi Dan Bisnis, 11(1), 14-28.

Sugiyono. (2017). Metode Penelitian Kuantitatif, Kualitatif, dan RED. Bandung: CV Alfabeta.

Sukasih, A., \& Sugiyanto, E. (2017). Pengaruh Struktur Good Corporate Governance dan Kinerja Lingkungan Terhadap Pengungkapan Corporate Social Responsibility (Studi Pada Perusahaan Manufaktur di Bursa Efek Indonesia Periode 2011-2015). Riset Akuntansi Dan Keuangan Indonesia, 2(2), 121-131. https:// doi.org/10.23917/ reaksi.v2i2.4894

Wagner, M., \& Schaltegger, S. (2004). The effect of corporate environmental strategy choice and environmental performance on competitiveness and economic performance: an empirical study of EU manufacturing. European Management Joutnal, 2(5), 557-572.

Wedayanti, L. P., \& Wirajaya, I. G. A. (2018). Pengaruh Pengungkapan Corporate Social Responsibility Pada Nilai Perusahaan Dengan Ukuran Perusahaan Sebagai Variabel Moderasi Fakultas Ekonomi dan Bisnis Universitas Udayana ( Unud ), Bali - Indonesia email: putriw. E-Jurnal Akuntansi Universitas Udayana, 24(3), 2304-2332.

Wickert, C. (2014). Political" corporate social responsibility in small-and medium-sized enterprises: A conceptual framework'. Business and Society. https://doi.org/10.1177/0007650314537021

Wickert, Christopher, Scherer, A. G., \& Spence, L. J. (2016). Walking and Talking Corporate Social Responsibility: Implications of Firm Size and Organizational 
Cost. Journal of Management Studies, (100018), 1-50.

Widyastari, N. K. W., \& Sari, M. M. R. (2018). Pengaruh Ukuran Perusahaan, Proporsi Dewan Komisaris Independen, dan Kepemilikan Asing Pada Pengungkapan Corporate Social Responsibility Fakultas Ekonomi dan Bisnis Universitas Udayana ( Unud ), Bali , Indonesia Fakultas Ekonomi dan Bisnis Universitas U. E-Jurnal Akuntansi Univesitas Udayana, 22(2), 1826-1856.

Wulandari, A. A. A. I., \& Sudana, I. P. (2018). Pengaruh Profitabilitas, Kepemilikan Asing, Kepemilikan Manajemen, dan Leverage Pada Intensitas Pengungkapan Corporate Social Responsibility. E-Jurnal Akuntansi, 22, 1445. https://doi.org/10.24843/EJA.2018.v22.i02.p23 